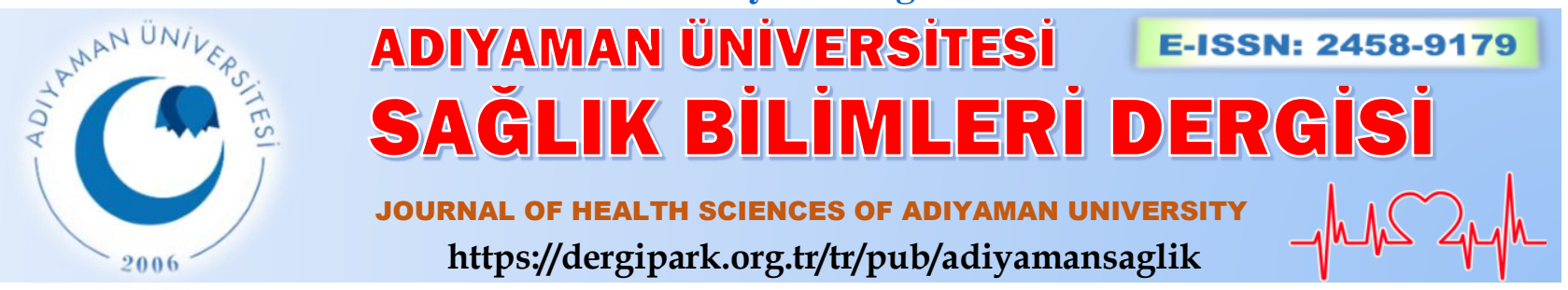

\author{
Özgün Araştırma/Research Article
}

\title{
Van bölgesinde çocukluk çağı artritlerinin tanısal dağılımı
}

\section{Diagnostic distribution of childhood arthritis in Van region}

\author{
Haci BALLI $1 @$, İbrahim ECE ${ }^{2}(D)$ \\ ${ }^{1}$ Adıyaman Üniversitesi Eğitim Araştırma Hastanesi, Kadın Doğum ve Çocuk Hastanesi, 02040, Adıyaman-Türkiye \\ ${ }^{2}$ Türkiye Yüksek İhtisas Eğitim ve Araştırma Hastanesi, 06230, Ankara-Türkiye
}

Atıf gösterme/Cite this article as: Ballı H, Ece İ. Van bölgesinde çocukluk çağı artritlerinin tanısal dağılımı. $A D Y \ddot{U}$ Sağlık Bilimleri Derg. 2020;6(2):190-196. doi:10.30569.adiyamansaglik.647627

Öz

Amaç: Artrit, sıklıkla eklemleri tutan ve eklemde şişlik, ağrı, 1sı artışı, kızarıklık ve eklemde fonksiyon kaybına neden olabilen eklem inflamasyonudur. Çocuklarda artrite birçok hastalık neden olabilir. $\mathrm{Bu}$ hastalıklar enfeksiyöz, romatizmal, hematolojik veya ortopedik hastalıklar olabilir. Çalışmamızda pediatri polikliniklerimizde artrit tanısı konulan çocukların tanısal dağılımının retrospektif olarak değerlendirilmesi amaçlanmıştır.

Gereç ve Yöntem: $\mathrm{Bu}$ çalışmada Yüzüncü Yı1 Üniversitesi Dursun Odabaş Tıp Merkezi Eğitim ve Araştırma Hastanesi Çocuk polikliniklerine Ocak 2010-Eylül 2013 tarihleri arasında artrit tanısı alan 340 olgu retrospektif olarak incelendi.

Bulgular: Artritle başvuran hastalar tanılara göre sıralandığında, Akut Romatizmal Ateş (\%38,5), Brusellozis $(\% 27,6)$ ve Henöch Schönlein Purpurası $(\% 24,7)$ en s1k görülen nedenlerdi.

Sonuç: Çalışmamızda ARA artriti, brusella artriti ve HSP artriti en sık görülen hastalıklar olarak dikkat çekmiştir. Pastörize süt ve süt ürünleri kullanımının arttırılmasının bölgemizdeki brusella artriti oranlarını azaltabileceğini düşünmekteyiz. Sonuçlarımızın çok merkezli ve yeterli sayıda çalışmalarla desteklenmesi gerektiğini düşünüyoruz

Anahtar Kelimeler: Artrit; Çocuk; Tanı; Dağılımı.

\begin{abstract}
Aim: Arthritis is a joint inflammation involving the joints and may cause swelling, pain, temperature increase, redness and loss of function in the joint. Arthritis in children can cause many diseases. These diseases can be infectious, rheumatic, hematological or orthopedic diseases. The aim of this study was to evaluate the clinical and laboratory characteristics of children diagnosed with arthritis in our pediatric outpatient clinics retrospectively.

Materials and Methods: In this study, 340 cases diagnosed as arthritis between January 2010 and September 2013 were investigated retrospectively to Yüzüncü Y1l University Dursun Odabaş Medical Center Training and Research Hospital Pediatric Outpatient Clinics.

Results: Acute Rheumatic Fever (38.5\%), Brucellosis (27.6\%) and Henöch Schönlein Purpura (24.7\%) were the most common causes when patients who presented with arthritis were ranked by diagnosis.

Conclusion: In our study, ARA arthritis, brucella arthritis and HSP arthritis were the most common diseases. We believe that increasing the use of pasteurized milk and dairy products may reduce the rates of brucella arthritis in our region. We believe that our results should be supported by multicentre and sufficient studies.
\end{abstract}

Keywords: Arthritis; Child; Diagnosis; Distribution.

Yazışma Adresi/Address for Correspondence: Haci BALLI, Adıyaman Üniversitesi Eğitim Araştırma Hastanesi, Kadın Doğum ve Çocuk Hastanesi, 02040, Adıyaman-Türkiye, E-mail: haciballi02@ hotmail.com

Geliş Tarihi/Received:16.11.2019 Kabul Tarihi/Accepted:10.05.2020

Yayım Tarihi/Published online:30.08.2020

Bu eser, Creative Commons Atıf-GayriTicari 4.0 Uluslararası Lisansı ile lisanslanmıștır. Telif Hakkı @ 2020 Adıyaman Üniversitesi Rektörlüğü 


\section{Giriş}

Artrit, s1klıkla eklemleri tutan ve eklemde şişlik, ağrı, 1sı artışı, kızarıklık ve eklemde fonksiyon kaybina neden olabilen eklem inflamasyonudur. Pediatrik hastaların \%7-8'i eklem ağrısı şikayetinden polikliniğe başvururken, bu çocukların sadece \%1'inde ileriki dönemde artrit gelişir. ${ }^{1}$

Çocukluk çağında pekçok enfeksiyöz, romatizmal, hematolojik veya ortopedik hastalık artrite neden olabilir (Tablo 1). ${ }^{2}$ Ayırıcı tanı yapılırken hastanın yaşı, geçirilmiş enfeksiyonlar ve travma, tutulan eklem sayıs1, artritin süresi, artritin simetrik olup olmadığı, artrite sistemik bulguların eşlik edip etmediği ve aile öyküsü önem kazanır. Ayrıca fizik muayenede ateş, döküntü, lenfadenopati, organomegali, üfürüm olması bizi spesifik hastalığa yönlendirebilir.

Tablo 1. Çocuklarda artritle ortaya çıkabilecek olan hastalıklar.

\begin{tabular}{l}
\hline A-İnfla mat uar ha st alıklar \\
Akut romatizmal ateş \\
Jüvenil idyopatik artrit \\
Spondilartropatiler \\
Vaskülitler \\
Sistemik lupus eritematosus \\
Bağ dokusu hastalıkları \\
Ailesel akdeniz ateşi \\
B-Enfeksiyöz hastalıklar \\
Septik artrit \\
Osteomiyelit \\
Selülit \\
Diskit \\
İnfektif endokardit \\
Enterik enfeksiyonlar \\
Bruselloz \\
Viral enfeksiyonlar \\
Tüberküloz \\
C-Mekanik-ortopedik durumlar \\
Travma \\
Aseptik nekrozlar \\
İskelet displazileri \\
D- Hematolojik/onkolojik nedenler \\
Lösemi \\
Lenfoma \\
Kemik tümörleri \\
Yumusak doku tümörleri \\
Hemofililer \\
Orak hücreli anemi \\
E- Diğerleri \\
Reaktif postenfeksiyöz artrit \\
\end{tabular}

Özellikle ilk basamak laboratuar tetkikleri olarak yapilan hemogram, eritrosit sedimentasyon hızı, C reaktif protein (CRP),
Romatoid faktör (RF), Antistreptolizin O (ASO) tanıyı kolaylaştıran tetkiklerdir. Artritli hastaların hikayesinde ağrının oluşma zamanı önem kazanır. Akut ağrılarda akla daha çok enfeksiyöz hastalıklar ve travma, kronik ağrilarda ise genellikle inflamatuvar, ortopedik veya dejeneratif hastaliklar akla gelir. $^{2}$

Çalışmamızda pediatri polikliniklerimizde artrit tanısı konulan çocukların tanısal dağılımını retrospektif olarak inceleyip literatüre katkıda bulunmayı amaçladık.

\section{Gereç ve Yöntem}

$\mathrm{Bu}$ çalışma Yüzüncü Y1l Üniversitesi Dursun Odabaş Tıp Merkezi Egitim ve Araştırma Hastanesi Çocuk polikliniklerine 01.01.2010-01.09.2013 arasındaki tarihlerde artrit tanısı alan (eklemde ağrı, şişlik, kızarıklık, ısı artışı ve hareket kısıtlılığının en az iki bulgunun birlikte olması şartıyla) başvuran 393 hastadan 53 tanesi veri eksikliği nedeniyle çalışma dişı bırakıldı. Çalışmaya alınan 340 hasta retrospektif olarak incelendi. Çalışmaya 0-18 yaş arası kız ve erkek çocukları dahil edildi.

Eklem tutulum sayılarına göre 4'ten daha fazla eklem tutulumu poliartrit, 4 veya daha az eklem tutulumu oligoartrit, sadece bir eklem tutulumu monoartrit olarak ifade edildi.

Akut romatizmal ateş (ARA) tanısı modifiye cons kriterleri kullanılarak konulmuştu. $^{3}$ Juvenil idiopatik artrit (JiA) tanısı klinik ölçütlere göre konuldu. Hastalığın özgün bir laboratuvar verisi yoktur. ${ }^{1}$ Brusella tanısında Wrigt aglütinasyon testi kullanıldı. 1/160 ve üzeri değerler pozitif kabul edildi. Henöch Schönlein Purpuras1 (HSP) tanis1 1990 Amerikan Romatoloji Birliği tanı ölçütleri kullanılarak konuldu. Tanı için en az iki ölçütün bulunması gereklidir. ${ }^{4}$ Ailesel akdeniz ateşi (FMF) tanısı klinik bulgularla konuldu. Genetik tanı klinik olarak şüphelenilen olgularda yapıldı. Hastalığın tanısına yönelik çeşitli tanı kriterleri olmakla birlikte, bugün sıklıkla TelHashomer kriterleri kullanılmaktadır., Septik artrit ve osteomyelit tanıs1 eklem boşluğundan sinovyal sıvı aspirasyonu ve bu sıvının gram boyama ve kültürü ile konuldu. ${ }^{7}$ Poststreptokoksik reaktif artrit (PSRA) tanıs1 
gezici artriti olmayan (ARA'dan farklı olarak) ve A grubu streptokok varlığ gösterilmesi ile klinik olarak konuldu. Malignite (ALL) tanısı ise kemik iliği aspirasyonu ile konuldu.

\section{İstatistiki değerlendirme}

İstatistiksel analizler için SPSS (Statistical Packagefor Social Sciences) 16.0 program1 kullanıldı. Verilerin analizinde tamamlayıcı istatistiksel yöntemlerin yanısıra, niceliksel testlerin karşılaştırılmasında nonparametrik testler ve T-Test kullanıldı. Sonuçlar \%95 güven aralığında ve $p<0,05$ anlamlı olarak kabul edildi.

\section{Bulgular}

Çalışmada hastaların $(\% 53,8)$ 'i erkek, $(\% 46,2)$ 'si kadınlardan oluşuyor idi. Hastaların başvuru sırasındaki yaşları 1-16

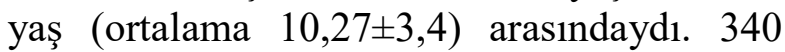
hasta tanılara göre siralandiğında ARA $(\% 38,5)$, Brusellozis $(\% 27,6)$ ve HSP $(\% 24,7)$ en sık görülen hastalıklar iken, JİA $(\% 2,6)$, FMF $(\% 2,4)$, PSRA $(\% 1,2)$, septik artrit $(\% 0,9)$, salmonella $(\% 0,6)$, ve malignite $(\% 0,6)$ daha az sıklıkta görülen hastalıklardı. $3(\% 0,9)$ hastada ise herhangi bir tan1 konulamadığı görüldü (Şekil 1).

Şekil 1. Artritli olguların tanılara göre dağılımı.

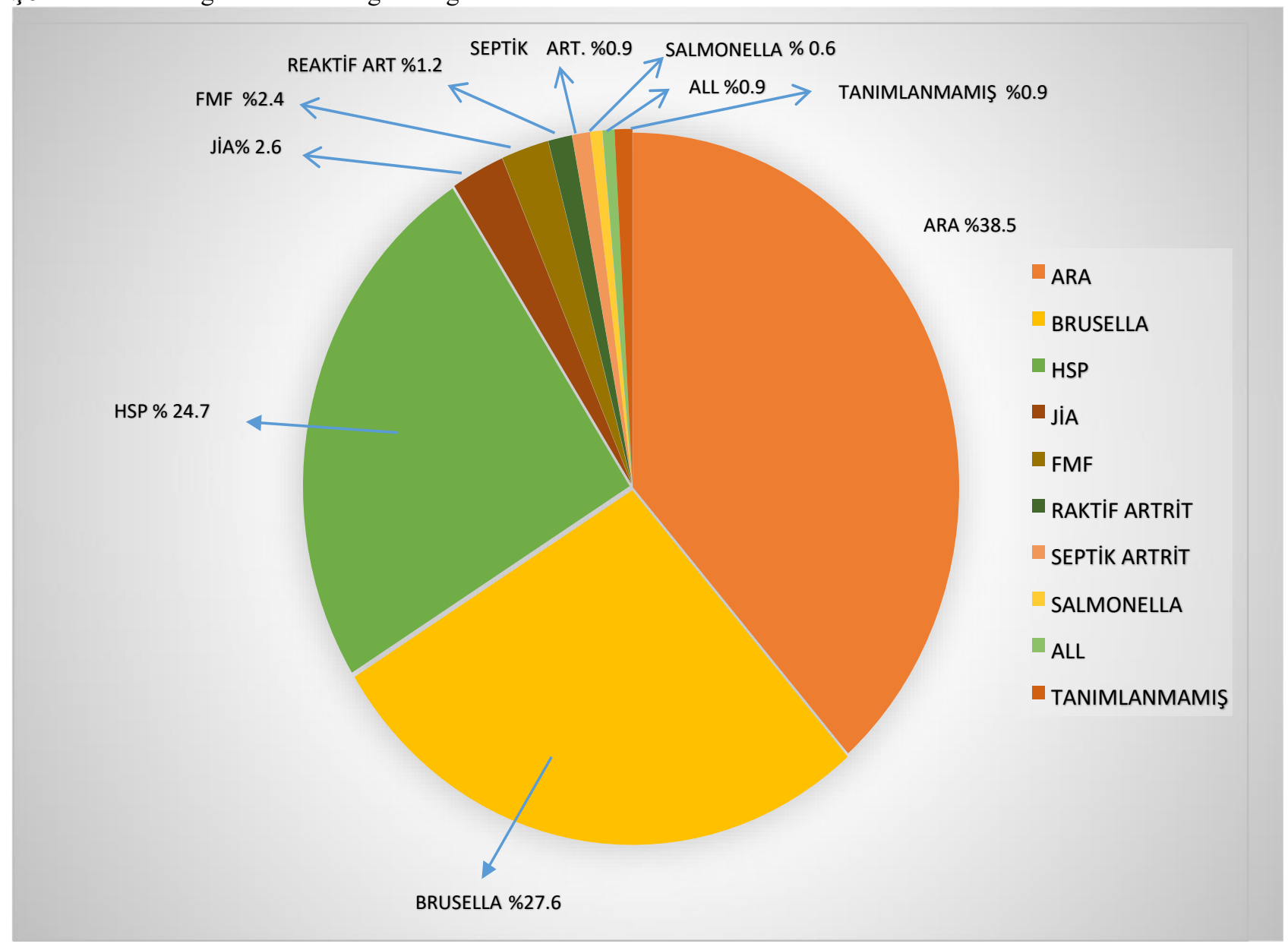

ARA: Akut romatizmal ateş, HSP:Henöch Schönlein Purpurası, JİA: Juvenil İdiopatik Artrit, FMF: Ailevi Akdeniz Ateşi, ALL: Akut lenfoblastik lösemi

Olgular tanılara ve cinsiyetlere göre incelendiğinde Brusella, HSP ve JİA da erkek/kadın oranı diğer gruplarla kıyaslandığında belirgin daha yüksek saptandı $(p: 0,001)$. ARA ve diğer gruplarda ise erkek/kız oranı arasında belirgin fark saptanmadı $(p>0,05)$ (Şekil 2).
Artritli vakalar eklemlerin tutulum sayılarına göre değerlendirildiğinde vakaların $\% 25$ 'i poliartrit, $\% 49,4$ 'ü oligoartrit, $\% 24,7$ 'i monoartrit eklem tutulum olarak sınıflandırılmıştı. Hastaların tutulan eklem bölgeleri irdelendiğinde diz eklemi $(\% 38,8)$, ayak bileği eklemi (\%38) ve el bileği eklemi $(\% 11,7)$ en sik tutulan eklemler idi. Brusellada kalça eklem tutulumu diğer 
guruplara göre belirgin fazla idi $(p: 0,001)$. HSP'de ayak bileği tutulumu diğer gruplara kıyasla daha fazla bulundu (Tablo 2).

ARA'lı olgularda poliartrit görülme sıklığ1 diğer gruplarla kiyaslandığında anlamlı yüksek bulundu ( $p: 0,001)$. HSP'li olgularda oligoartriküler eklem tutulumu görülme sıklığı diğer gruplarla kıyaslandığında anlamlı yüksek bulundu ( $p: 0,001)$ (Tablo 3$)$.

Olgularımızın laboratuar verileri incelendiğinde ARA'lı olguların ortalama sedimentasyon, CRP ve lökosit değerleri diğer gruplarla kıyaslandiğında anlamlı yüksek bulundu $(p<0,05)$. Yine Brusellalı olguların ortalama sedimentasyon, CRP ve lökosit değerleri diğer gruplarla kıyaslandığında anlamlı düşük bulundu $(p<0,05)$. Riise ve ark.nın, Noah ve ark.nın ve Kıplapınar ve ark.nın yaptıkları çalışmalarda lökosit değerinin gruplar arasında ayırıcı olmadığı gözlemlenmiş., $8,9,10$

Şekil 2. Artritli olguların tanılara ve cinsiyete göre dağılımı

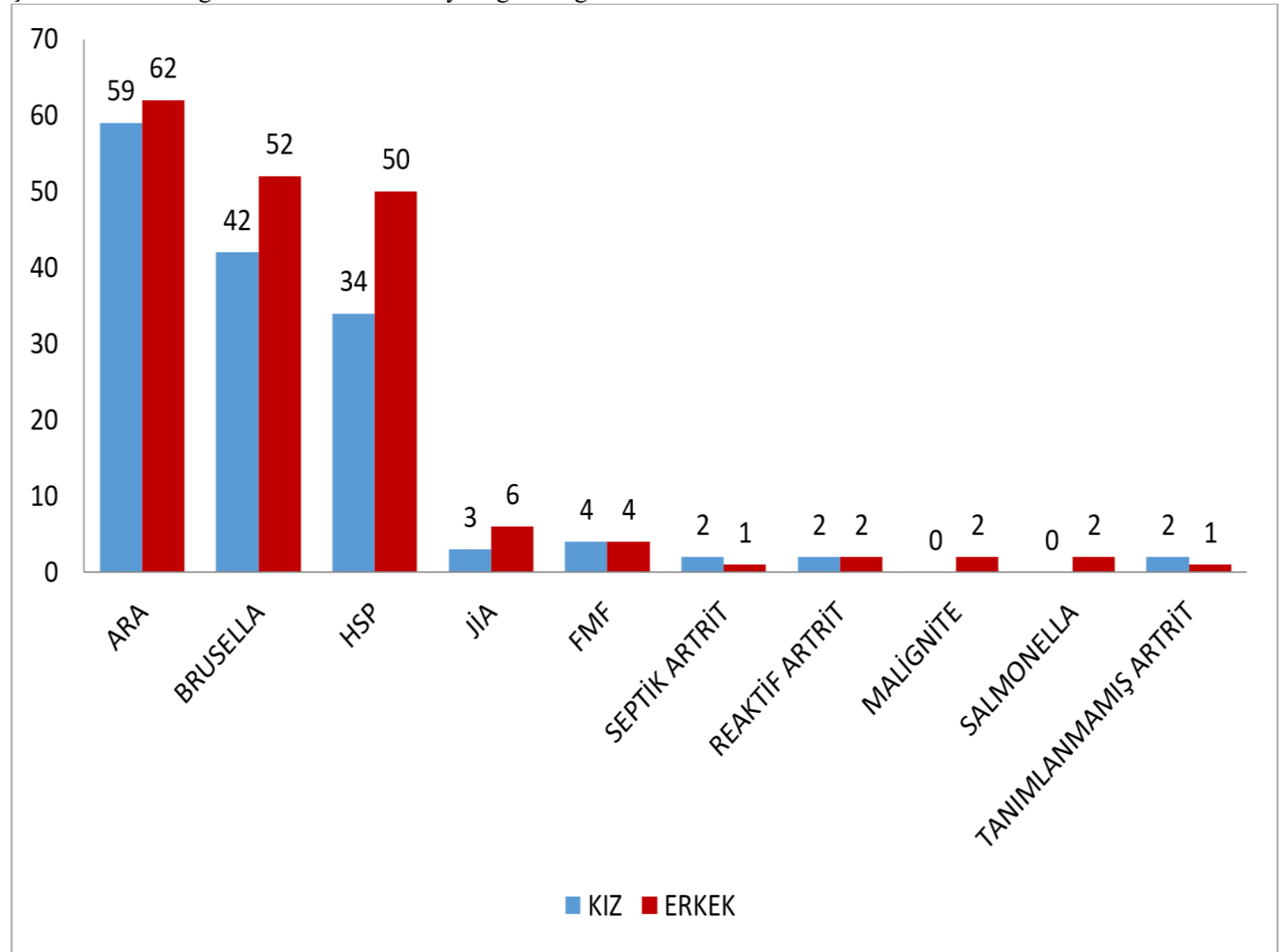

ARA:Akut romatizmal ateş, HSP:Henöch Schönlein Purpurası, JİA:Juvenil İdiopatik Artrit, FMF:Ailevi Akdeniz Ateşi,

\section{Tartışma}

Çocukluk dönemde birçok enfeksiyöz, romatizmal, hematolojik veya ortopedik hastalık artrite sebep olabilmektedir. Ateş ile beraber olan monoartrit varlığında enfeksiyöz nedenler akla gelmelidir ve özellikle de osteomyelit ve septik artrit göz önünde bulundurulması gereken iki önemli hastalıktır. A grubu beta hemolitik streptokoklarin $(G A B H S)$ neden olduğu tonsilofarenjit sonrası meydana gelen ARA, daha çok eklemleri ve kalbi, daha nadir olarak santral sinir sistemini ve cildi tutan sistemik bir hastalıktır. Gelişmekte olan ülkelerde romatizmal kardit halen önemli bir morbidite sebebiyken, gelişmiş ülkelerde uygun dozda antibiyoterapi ile birlikte ARA az görülen hastalıklar arasına girmiştir. JIA, eksojen veya endojen antijenlerin sebep olduğu daha çok periferik artrit ile ortaya çıkan, immun sistemde artan inflamatuar cevapla belirginleşen bir çocukluk çağı hastalığıdır. ${ }^{1,11}$ Brusella 
hastalığı (Ondulan ateş, Akdeniz ateşi, Malta humması, Bang's hastalığı) Brusella cinsi bakterilerin neden olduğu birincil olarak bir hayvan hastalığıdır. Keçi, koyun, sığır, manda ve domuzların sütleri, etleri, idrar ve kan gibi vücut sıvıları yada enfekte sütten hazırlanan süt ürünleri, iyi kaynatılmamış süt, infekte hayvanın düşük materyali gibi biyolojik materyaller ile insanlara bulaşabilen, ateş, terleme, iştahsızlık, eklemlerde ve kaslarda ağrilarla kendini gösteren bir zoonozdur. ${ }^{12,13}$ HSP etyolojisine yönelik çalışmaları devam eden siklıkla ciltte olmak üzere eklemler, gastrointestinal sistem, böbrekler ve nadir olarak da diğer organların etkilendiği bir lökositoklastik vaskülittir. Yaygın olarak 5-15 yaş arası çocuklar etkilenir. Bu nedenle HSP çocukluk dönemi hastalığ 1 olarak kabul edilebilir. ${ }^{14,15}$ FMF otozomal ressesif bir hastalık olup, karın ağrısı, tekrarlayan ateş ve

Tablo 2: Olguların tutulan eklem yerine göre dağılımı serozal inflamasyona bağlı epizotların yanında akut faz cevabının da olduğu çoğunlukla kendini sınırlayan bir hastalıktır. Başlıca bulguları ateş, peritonit, artrit, plörit ve erizipel benzeyen deri döküntüleridir. ${ }^{16}$ Septik Artrit ve Osteomyelit çocuklarda kemik ve eklemleri etkileyen ve kalıcı sakatlığa neden olabildiklerinden önemle üzerinde durulması gereken hastalıklardır. En sik nedeni bakterilerdir. Septik artritte ve osteomyelitte her yaşta S.aureus en s1k etkendir. Bundan sonra A grubu sterptokoklar ve pnömokoklar gelmektedir. ${ }^{17}$ PSRA daha kısa süre önce geçirilmiş tonsilofarenjitin ardından (ARA' ya göre) gelişen akut başlangıçlı bir artrittir. Latent period 3-10 gün kadar sürer. PSRA, ARA' dan farklı olarak gezici tarzda artrit geliştirmez. Daha çok büyük eklemleri ve genellikle alt ekstremite eklemlerini tutar. ${ }^{18}$

\begin{tabular}{|c|c|c|c|c|c|c|c|}
\hline Tanı & Diz & Ayak bileği & El bileği & Kalça & Dirsek & Omuz & El küçük eklem \\
\hline ARA & $98(\% 28)$ & $110(\% 32)$ & $44(\% 12)$ & $14(\% 4)$ & $4(\% 1,1)$ & $5(\% 1,4)$ & $8(\% 2,3$ \\
\hline Brucella & $82(\% 24)$ & $23(\% 6,7)$ & $8(\% 2,3)$ & $33(\% 9,7)$ & $2(\% 0,5)$ & 0 & $1(\% 0,2)$ \\
\hline HSP & $60(\% 17)$ & $111(\% 32)$ & $14(\% 4)$ & $2(\% 0,5)$ & 0 & 0 & 0 \\
\hline JİA & $11(\% 3)$ & $9(\% 2,6)$ & $3(\% 0,8)$ & $1(\% 0,2)$ & 0 & 0 & $4(\% 1,1)$ \\
\hline FMF & $9(\% 2,6)$ & $5(\% 1,2)$ & $4(\% 1,1)$ & $1(\% 0,2)$ & 0 & 0 & 0 \\
\hline Reaktif artrit & $5(\% 1,2)$ & $2(\% 0,5)$ & $4(\% 1,1)$ & $1(\% 0,2)$ & 0 & 0 & 0 \\
\hline Septik artrit & $1(\% 0,2)$ & 0 & 0 & $1(\% 0,2)$ & 0 & $1(\% 0,2)$ & 0 \\
\hline $\begin{array}{l}\text { Malignite } \\
\text { (ALL) }\end{array}$ & 0 & $2(\% 0,5)$ & $1(\% 0,2)$ & 0 & 0 & $1(\% 0,2)$ & 0 \\
\hline Salmonella & $3(\% 0,8)$ & 0 & 0 & 0 & 0 & 0 & 0 \\
\hline $\begin{array}{l}\text { Tanımlanmamış } \\
\text { artrit }\end{array}$ & 0 & $1(\% 0,2)$ & $3(\% 0,8)$ & 0 & 0 & 0 & 0 \\
\hline Toplam sayı (n) & 269 & 263 & 81 & 53 & 6 & 7 & 13 \\
\hline (\%) & $\% 38,8$ & $\% 38,0$ & $\% 11,7$ & $\% 7,6$ & $\% 0,86$ & $\% 1$ & $\% 1,8$ \\
\hline
\end{tabular}

Tablo 3. Artritli olguların tutulan eklem sayısına göre dağılımı.

\begin{tabular}{lllll}
\hline Tanı & Monoartrit Sayı/\% & Oligoartrit Say $/ \%$ & Poliartrit Say1/\% & Toplam Say1/\% \\
\hline ARA & $12 / 9,1$ & $37 / 28,2$ & $79 / 60,3$ & $131 / 100$ \\
Brusella & $45 / 47$ & $49 / 53$ & $0 / 0$ & $94 / 100$ \\
HSP & $13 / 15,4$ & $70 / 83,3$ & $1 / 1,1$ & $84 / 100$ \\
JíA & $1 / 11,1$ & $5 / 55,5$ & $3 / 33,3$ & $9 / 100$ \\
FMF & $4 / 50$ & $3 / 37,5$ & $1 / 12,5$ & $8 / 100$ \\
Reaktif Artrit & $2 / 50$ & $1 / 25$ & $1 / 25$ & $4 / 100$ \\
Septik Artrit & $3 / 100$ & $0 / 0$ & $0 / 0$ & $3 / 100$ \\
Malignite (All) & $0 / 0$ & $2 / 100$ & $0 / 0$ & $2 / 100$ \\
Salmonella & $1 / 50$ & $1 / 50$ & $0 / 0$ & $2 / 100$ \\
Tanımlanmamış Artrit & $3 / 100$ & $0 / 0$ & $0 / 0$ & $3 / 100$ \\
\hline TOPLAM & $84 / 24,7$ & $168 / 49,4$ & $85 / 25$ & $340 / 100$ \\
\hline
\end{tabular}

Yabancı kaynaklarda, çocukluk çağı artritlerinin etyolojik sinıflaması hakkında sınırlı sayıda çalışma mevcuttur ve farklı çalışmalarda farklı oranlar ifade edilmiştir. Riise ve ark. ${ }^{8}$ Kuzey Avrupa ülkesi Norveç’te çok merkezli olarak yaptıkları çalışmalarında 
artrit sıklığının 100.000 de 71 olduğunu belirtmişlerdir. Riise ve ark. nın çalışmasında toksik sinovitin birinci surada artit nedeni olduğu ve sıklığı 100.000 de 43 olduğunu deklare etmişlerdir. JİA 100.000 de 14, PSRA 100.000 de 9 ve infeksiyöz artrit (septik artrit ve osteomyelit) 100.000 de 5 oranında bulunmuştur. ${ }^{8}$ Bir başka çalışmada Noah ve ark. ${ }^{9} 65$ artritli olguyu etyolojilerine yönelik yaptıkları çalışmada JİA $(\% 28)$ oranı ile birinci suradaki artrit nedeni olarak bulunmuştur. Diğer hastalıkların görülme sıklığı sirasıyla PSRA \%20'i, ARA \%15'i ve \%12'si ise SLE idi. ${ }^{9}$ Her iki çalışma ile kıyaslandığında; çalışmamızda ARA artriti, brusella artriti ve HSP artriti oranı belirgin yüksek saptanmıştı. Risse ve ark. ${ }^{8}$ nın çalışmasının bizden en büyük farklılığ 1 sadece kronik artrit vakalarını incelemiş olması idi. Bölgemizde düşük sosyo-ekonomik nedenlerden dolayı pastörize süt ve süt ürünleri tüketiminin az olmasının, brusella artriti oranlarını arttırdığını düşünmekteyiz. Her iki çalışma dikkate alındığında ARA artriti oranımızın da belirgin yüksekliğinde, hastaların düşük sosyo-ekonomik nedenlerden dolayı sağlık kuruluşlarına geç başvurmasının katkısı olduğunu düşünüyoruz. Ayrıca, Noah ve ark. ${ }^{9}$ nın sadece yatan artritli hastaları çalışmaya almaları oranlarımız arasında farklılıklar oluşmasına yol açmış olabilir.

Ülkemizde Kıplapınar ve ark. ${ }^{10}$ nın 2008 2009 yılları arasında 100 pediatrik hastada yaptıkları prospektif çalışmada ARA \% 41, PSRA $\% 27$, JİA $\% 9$, FMF $\% 6$, HSP $\% 4$, brusella artriti $\% 2$, spondilartropati $\% 2$, eritema nodozum $\% 2$, ürtikeryal artrit $\% 2$, Weber-Christian hastalig1 \%1, hemartroz \% 1 , osteomyelit \%1, septik artrit $\% 1$ ve malignite (nöroblastom) \%1 olarak bulunmuş. ${ }^{10}$ Ağzıkuru ve ark. $^{19}$ nın 2000-2002 y1lları arasında yatırılarak takip edilen 39 hastanın retrospektif çalışmalarında ARA $(\% 38,6)$, JİA $(\% 20,5)$, septik artrit $(\% 15,2)$, reaktif artrit $(\% 7,69)$, sinovit $(\% 5,2)$, Behçet hastalı̆̆ $(\% 2,56)$ ve vaskülit $(\% 2,56)$ olarak bulunmuş. ${ }^{19}$ ARA artriti oranlarımız her iki çalışma ile uyumluluk göstermiştir. Ancak; JIA, PSRA ve septik artrit oranlarımız belirgin düşük iken; brusella artriti ve HSP artriti oranlarımız da yüksekti. $\mathrm{Bu}$ oranlar arasındaki farklılıkta etkili birkaç faktör olduğunu düşünüyoruz. Öncelikle her iki çalışma yatan hastalarda yapılmıştı. Bu durum ayaktan da izlenebilecek olan hastaları çalışma dışı bırakmıştır. HSP artrit oranımız bu nedenle daha yüksek olmuş olabilir. Çünkü; kliniğimizde bu hastaların çoğu ayaktan izlenmektedir. Ayrıca, bölgemizde hayvancılığın yaygın olması ve pastörize süt ve süt ürünlerinin tüketim oranlarının düşük olması da brusella artriti oranlarını arttırmış olabilir.

Çalışmamızda birtakım kısıtlılıklar mevcuttur. Öncelikle retrospektif çalışma olduğu için bazı hastaların dosyalarındaki verilere ulaşılamadığ 1 için çalışma dış1 bırakıldı. Tek merkez verisinin paylaşıldı ${ }_{1}$ için; bölgesel epidemiyolojik verileri yansitmakta olsa da veriler ülke geneline uygulanamaz. Bu da önemli bir kısitl1lıktır.

\section{Sonuç}

Sonuç olarak; çalışmamızda ARA artriti, brusella artriti ve HSP artriti en s1k görülen hastalıklar olarak dikkat çekmiştir. Pastörize süt ve süt ürünleri kullanımının arttırılmasının bölgemizdeki brusella artriti oranlarını azaltabileceğini düşünmekteyiz. Sonuçlarımızın çok merkezli ve yeterli sayıda çalışmalarla desteklenmesi gerektiğini düşünüyoruz.

\section{Araştırmanın Etik Boyutu}

Araştırma süresince İnsan Hakları Helsinki Deklarasyonu'na sadık kalındı. Araştırma verilerinin toplandiğ 1 hastanenin başhekimliğinden ve çocuk sağlığı ve hastalıkları kliniğinden çalışmanın amaç ve kapsamını içeren bir bilgi formu ile başvurularak yazılı izin alındı. İlgili üniversitenin Tıp Fakültesi Etik Kurulu'ndan yazılı izin alınd1 (30.01.2014, sayı:03).

\section{Yazar katkıları}

Konsept: H.B, İ.E. Dizayn: H.B., Veri Toplama veya İşleme: H.B., Analiz veya Yorumlama: H.B., İ.E, Literatür Arama: H.B., İ.E., Yazan: H.B.

\section{Çıkar Çatışması Beyanı}

Yazarların herhangi bir çıkara dayalı ilişkisi yoktur. 


\section{Araştırma Desteği}

Çalışmayı maddi olarak destekleyen kişi/kuruluş yoktur.

\section{Beyanlar}

$\mathrm{Bu}$ çalışma, 4-6 Mayıs 2018 tarihinde, Şanlıurfa'da düzenlenen 1.Uluslararası Gevher Nesibe Sağlık Hizmetleri Kongresinde (GAP zirvesi) sözel bildiri olarak sunulmuştur.

\section{Kaynaklar}

1. Petty RE, Cassidy JT. Textbook of PediatricRheumatology. Elsewier Saunders Company. 2005:206-341.

2. Kasapçopur Ö. Çocukluk çağı romatizmal hastalıklarına tanılandırıcı yaklaşım. İ.Ü. Cerrahpaşa Tıp Fakültesi Sürekli Tıp Etkinlikleri, Sempozyum dizisi 2003; 34(1): 43-50.

3. WHO. Rheumatic fever and rheumatic heart disease: report of a WHO Expert Consultation)

4. Mills JA, Michel BA, Bloch DA, et al. The American College of Rheumatology. 1990 Criteria for classification of HenochSchönlein purpura. Arthritis Rheum 1990; 33:1114-21.

5. Soher E, Gafni J, Pras M et al. Familial Mediterranean Fever; A survey of 470 cases and review oh the literature. Am J Med $1967 ; 227-53$.

6. Arısoy N, Kasapçopur Ö, Sever L, Çalışkan S, Yazıcı H, Özdoğan H. Clinical features of childhood familial Mediterranean fever proceedings book. Tel Aviv Freund Publishing House Ltd. 1997; 169-172.

7. Kothari NA, Pelchavitz DJ, Meyer JS: Imaging of musculoskeletal infections. Radiol Clin North Am 2001; 39:653-71.

8. Riise QR, Cvancarova M, Handeland KS, Nakstad B, Wathne KO, Abrahamsen TG, Kirkhus E, Flato B. Incidenceand Characteristics of Arthritis in Norwegian Children: A Population-Based Study. Pediatrics 2008;121; e299-e306.

9. Noah PK, De Ceulaer K. Arthritis in childhood. A report on 65 consecutive cases observed at the University Hospital of the West Indies. West Indian Med J. 1989;38 (1):17-22.

10. Kıplapınar N, Aydoğan G. Çocukluk Çağı Artritlerinin Etyolojisi. İstanbul Bakırköy Kadın Doğum ve Çocuk Hastalıkları Hastanesi Çocuk Kliniği, Uzmanlık Tezi. 2009

11. Zvaifler NJ, Klippel JH, Maini RN, Rheumatoid arthritis and other synovialdisorders. Rheum Dis Clin North Am. 1987;13(2):191-213.

12. Sözen TH, Söyletir G, Willke Topçu A, Doğanay M: Infeksiyon Hastalıklarl. Ankara: Nobel Tip Kitabevleri, 1996:486-491

13. Mutlu G, Mete Ö, İmir T, Ustaçelebi Ş, Cengiz T, Tümbay E, Temel ve klinik Mikrobiyoloji. Güneş Kitabevi. Ankara: 571577

14. Bagga A, Dillon MJ. Leukocytoclastic vasculitis. In: Cassidy JT, Petty RE (eds). Textbook of Pediatric Rheumatology WB Saunders Company. Philadelphia 2001; 569-79.

15. Yalçındağ A, Sundel R. Vasculitis in childhood. Curr Opin Rheumatol 2001; 13: 422-7.

16. Bakkaloğlu A.Familial Mediterranean Fever. Pediatr Nephrology 2003; 18:853-9

17. Bradley JS, Kaplan SL, Tan TQ, et al: PediatricPneumococcal bone and joint infections. The Pediatric Multicenter Pneumococcal Surveillance Study Group (PMPSG). Pediatrics 1998; 102:1376-82

18. Ayoub EM, Majeed HA. Poststreptococcal reactive arthritis. Curr Opin Rheumatol 2000; 12:306-10.

19. Ağzıkuru SB, Tokuç G, Öktem S, Tutar E, Artrit bulguları ile başvuran olgularımızın retrospektif incelenmesi Zeynep Kamil Tıp Bülteni 2004;35;1 